\title{
Ankle Dorsiflexors Strength Improves Balance Performance in Elderly: A Corelational Study
}

\author{
Shehab Mahmoud Abd El- Kader ${ }^{1}$, Eman M. Salah El-Den Ashmawy²
}

\begin{abstract}
The physical ability to maintain balance when moving and the ability to move independently are central requisites for independent living and are thus two important focuses in geriatric rehabilitation. It has been suggested that a decrease in the ability to generate force in the lower extremity muscles contribute to balance impairment and falling. The purpose of this study was to detect balance performance response to improved strength of dorsiflexors muscles in elderly. Fifty healthy elderly subjects, their age ranged 65-75 years, participated in this study. Twenty five subjects (training group) were trained with resisted exercises plus electrical nerve stimulation of ankle dorsiflexors muscles, three times a week for 8 weeks. The control group, included twenty five subjects, received no treatment intervention except encouragement for performing their usual activity of daily living over the 8 weeks of the study. The ankle dorsiflexors muscles force was measured by the hand held dynamometer in $\mathrm{Kg}$ and the balance control was measured by the Berg Balance Scale (BBS), the Functional Reach Test (FRT) and the Timed Get Up-Go Test (GUG). These measurements wevr5re applied for both groups before and after 8 weeks. The BBS, FRT and GUG values showed significant changes $(12.9 \%, 35.7 \%$ and $51.9 \%$ respectively) following training in the trained group. There were no significant changes $(0.67 \%$, $6.95 \%$ and $14.4 \%$ in the same measures of the control group after 8 weeks. Improved ankle dorsiflexors strength enhances balance performance in elderly
\end{abstract}

Key words: Balance, ankle dorsiflexors strength, resisted exercises, electrical nerve stimulation, elderly

\section{Ayak Bileği Dorsofleksör Kuvvetlendirmesi Yașlılarda Denge Performansını Artırır: Bir Korelasyon Çalıșması} ÖZET

Hareket sırasında dengeyi sağlama fiziksel yeteneği ve bağımsız hareket etme yeteneği bağımsız yaşamak için ana gerekliliklerdir ve geriatrik tıbbın iki önemli odak noktasıdır. Illeri sürülmüștür ki, alt eksremite kaslarında kuvvet olușturma yeteneğindeki düșüss denge bozukluğu ve düşmeye neden olmaktadır. Bu çalıșmanın amacı yaşlılarda dorsifleksör kaslarda yapılan kuvvet geliştirmeye karşı denge performansı değişimini araştırmaktı. Elli sağlıklı yaşı birey, yaşları 65-75 arasında değișen, çalıșmaya alındı. Yirmi beș bireye (egzersiz grubu) 8 hafta, haftada 3 kez direnç egzersizi artı ayak bileği dorsifleksör kaslara elektrik sinir uyası uygulandı. Yirmi beș kişiden oluşan kontrol grubuna çalıșma süresi olan 8 hafta boyunca rutin günlük yaşam aktivitelerini yapmaya teşvik dışında herhangi bir tedavi girişimi uygulanmadr. Ayak bileği dorsifleksör kas gücü kg olarak elle tutulan dinamometre ile ölçüldü ve denge kontrolü Berg denge Skalası (BDS). Fonksiyonel Reach Testi (FRT) ve Timed Get up Go Test (GUG) testi ile ölçüldü. Bu ölçümler her iki gruba başlangıçta ve 8 hafta sonra uygulandı. Çalışma grubunda çalışmayı takiben BDS, FRT ve GUG değerlerinde belirgin değişiklik görüldü (sırasıly \%12.9 \%35.7 ve \%51.9\%). Sekiz hafta sonunda kontrol grubunun aynı ölçüm değerlerinde belirgin değişiklik görülmedi (\%0.67, \%6.95 ve \%14.4). Artırılmış ayak bileği dorsifleksör kuvveti yaşılarda denge performansını geliștirir.

Anahtar kelimeler: Denge, ayak bileği dorsifleksör kuvveti, direnç egzersizi, elektrik sinir uyarısı, yașlı

'Department of Physical therapy for cardiopulmonary disorders and Geriatrics, Fac ulty of Physical Therapy, Cairo University, Egypt. '2Department of Physical therapy, Faculty of Applied Medical Sciences, King Abdulaziz University, Saudi Arabia.
Correspondence: Prof. Shehab Mahmoud Abd El- Kader , Faculty of Applied Medical Sciences, Department of Physical Therapy, King Abdulaziz University, P.O. Box 80324, Jeddah, 21589, Saudi Arabia.

Phone: +966-569849276 E. mail: profshehab@live.com

Received: 27.11.2012, Accepted: 18.04.2013 


\section{INTRODUCTION}

Falls are among the most common and serious problems facing elderly persons as $25 \%-35 \%$ of adults aged 65 years and older fall each year $(1,2)$. After the age of 75 years, the rates are higher (3). Falling is associated with increased mortality, morbidity, reduced functioning, loss of independence and premature hospital and geriatric admissions (4).

Diminished balance ability is multifactorial. It can be due to degeneration of visual and vestibular sensory systems, degeneration of proprioception or impairment of central processing or a combination of these factors. Lower extremity strength is a common factor associated with balance impairment in elderly fallers (5). Reduced lower extremity strength has been associated with reductions in gait speed, balance, stair-climbing ability and getting up from a seated position (6).

Muscle weakness is consistently associated with falls in the elderly people. It is becoming increasingly clear that adequate muscle strength is a key element for stable postural control. Indeed, epidemiological surveys have consistently identified muscle weakness as an important risk factor for falls in the elderly people. However, very little is known about the pathophysiology of instability and falls in such patient populations. Moreover, even less is known about how muscle weakness affects postural stability and leads to falls (7). Indeed, only very few studies have studied balance control in subjects with muscle weakness $(8,9)$. It has been shown before that muscle strength is a consistent risk factor for falls (7) and an independent predictor of postural sway in healthy older adults during standing on an unstable surface (10). The association between weak leg muscles and falling has led to a number of studies of strength training to enhance balance in balance-impaired older adults. These programs have evaluated the effects of strength training alone or in combination with other activities such as tai chi, aerobic exercise, and balance training (11-13). Dorsiflexion at the ankle joint and the tibialis anterior play important roles in maintaining balance (14). However, Lord et al . found that ankle dorsiflexion strength was 1 of 3 variables that significantly discriminated between older adults who had no falls or one fall and those with a history of multiple falls (15) .

The purpose of this study was to detect balance performance response to improved strength of dorsiflexors muscles in elderly.

\section{MATERIALS AND METHODS}

\section{Subjects}

Participants were community-dwelling elderly men, 60 to 65 years of age and because of the complex nature of balance control, exclusion criteria were extensive, they included health issues that could put subjects at risk for serious injury such as myocardial infarction in the last 6 months, recent angina, and poorly controlled hypertension (blood pressure $>160 / 90 \mathrm{~mm} \mathrm{Hg}$ ). Factors that could confound research data including diabetic neuropathy, history of cerebral vascular accident (stroke), severe congestive heart failure, Parkinson disease, diagnosed vestibular disorders, lower extremity joint replacements, or dementia were all reasons for exclusion. Potential participants were excluded if they used medicines known to impair balance ability, such as neuroleptics or benzodiazepines, or medications known to impair strength, such as prednisone. In addition, subjects needed to be ambulatory and were excluded if they were unable to walk ten meters without assistance. All participants were allowed to keep their routine regarding medications previously prescribed by their physicians.

Participants were divided into two equal groups; group (A) received electrical stimulation and resisted exercise training for ankle dorsiflexor muscles \& group (B) received no physical therapy intervention. Subjects were presented with a consent form before screening.

\section{Methods}

\section{Evaluated parameters}

\section{Clinical Measurement of Balance Ability}

The three balance measures were the BBS, FRT and GUG. The BBS consists of 14 tasks which are: (1) sit to stand, (2) standing unsupported, (3) sitting on stool, (4) stand to sit, (5) transfers, (6) standing with eyes closed, (7) standing with feet together, (8) reaching forward with an outstretched arm, (9) retrieving an object from the floor, (10) turning the trunk with feet fixed, (11) turning 360 degrees, (12) stool stepping, (13) tandem standing and (14) standing on one limb. These are scored from 0 to 4 , where 0 indicates an inability to perform the task and 4 indicates the task was performed correctly and independently. The maximal possible score on this test is 56 (16). The FRT was measured as the maximal distance 
Table 1.

\begin{tabular}{lllll} 
Characteristic & \multicolumn{2}{c}{ Mean +SD } & T-value & Significance \\
& Group (A) & Group (B) & & \\
\hline Age $(\mathrm{y})$ & \pm 62.253 .31 & \pm 60.873 .75 & 1.36 & $\mathrm{P}>0.05$ \\
Height $(\mathrm{cm})$ & $168.63 \pm 7.42$ & $170.32 \pm 6.14$ & 1.15 & $\mathrm{P}>0.05$ \\
Weight $(\mathrm{kg})$ & $70.65 \pm 4.93$ & $68.98 \pm 5.12$ & 1.21 & $\mathrm{P}>0.05$ \\
BMI $(\mathrm{kg} / \mathrm{m} 2)$ & $24.65 \pm 2.46$ & $23.87 \pm 2.65$ & 1.16 & $\mathrm{P}>0.05$ \\
\hline
\end{tabular}

Table 2. Mean values of BBS, FRT, GUG and ankle dorsiflexion muscles strength of group (A).

\begin{tabular}{lllll}
\hline & \multicolumn{2}{c}{ Mean +SD } & T-value & Significance \\
\hline BBS & Before & After & & \\
FRT $(\mathrm{cm})$ & $48.13 \pm 1.30$ & $54.40 \pm 1.68$ & 8.78 & $\mathrm{P}<0.05$ \\
GUG $(\mathrm{sec})$ & $38.40 \pm 1.84$ & $46.53 \pm 2.06$ & 8.21 & $\mathrm{P}<0.05$ \\
Ankle Dorsiflexion Muscle Force $(\mathrm{Kg})$ & $12.33 \pm 1.9$ & $18.73 \pm 1.67$ & 7.48 & $\mathrm{P}<0.05$ \\
\hline
\end{tabular}

FRT: Functional Reach Test. GUG: Timed Get Up Go Test

BBS: Berg Balance Scale.

that subjects could reach forward horizontally beyond arm's length while maintaining a fixed base of support in the standing position. The distance was measured (in centimeters) on a tape measure fixed to a wall. The $G$ $U$ G, measures the time in seconds taken for subjects to rise from an armchair, walk three meters, turn and return to the chair (17).

\section{Ankle dorsiflexion muscles force}

Hand held dynamometer (Penny and Giles, Biometrics Division, Blackwood Gwent NP2 IYD United Kingdom) was used for measuring ankle dorsiflexor and plantarflexor muscles strength. A stabilization frame was used for leg muscles strength with the subject in a long sitting position with the hip flexed between 70 and 80 degrees and the knee extended. The end piece of the dynamometer was applied to the dorsal surface of the foot proximal to

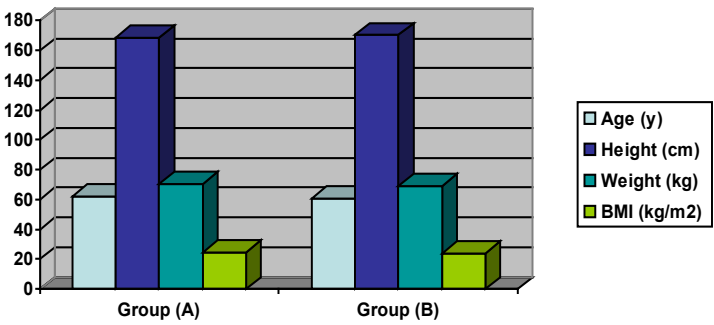

Figure 1. Mean values of Participant demographics in group (A) and group (B). the metatarsophalangeal joints to measure dorsiflexors muscle strength and on the plantar surface of the foot and also proximal to the metatarsophalangeal joints to measure plantarflexors muscle strength. Leg strength measurements were done in mid the range of the ankle joint and the subject asked to exert maximum force during the test. The mean of the three measurements was used for data analysis (18).

\section{Strength-Training Protocol}

Neuromuscular Electrical Stimulation program: Self adhesive electrodes were placed over common peroneal nerve near to the head of the fibula and over a motor point in the tibialis anterior muscle. The skin was marked with a permanent marker to standardize electrode placement across sessions. A sine wave with $2500 \mathrm{HZ}$ carrier frequency was delivered in 80 bursts per

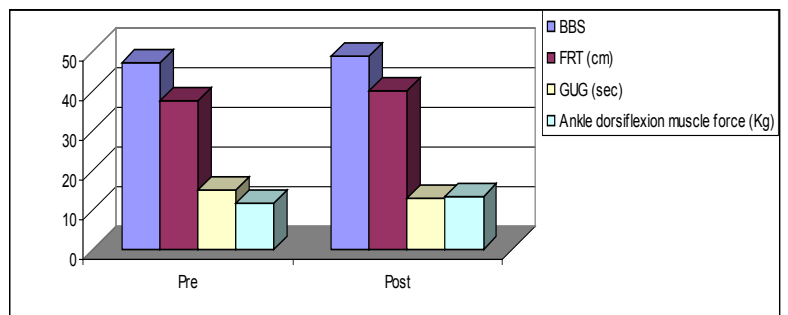

Figure 3. Mean values of BBS, FRT, GUG and ankle dorsiflexion muscles strength of group (B). 
Table 3. Mean values of BBS, FRT, GUG and ankle dorsiflexion muscles strength of group (B).

\begin{tabular}{lllll}
\hline & \multicolumn{2}{c}{ Mean +SD } & T-value & Significance \\
& Before & After & & \\
\hline BBS & $47.20 \pm 1.47$ & $48.60 \pm 1.72$ & 1.69 & $\mathrm{P}>0.05$ \\
FRT $(\mathrm{cm})$ & $37.40 \pm 2.56$ & $40.00 \pm 3.48$ & 1.55 & $\mathrm{P}>0.05$ \\
GUG $(\mathrm{sec})$ & $14.87 \pm 1.60$ & $12.73 \pm 2.12$ & 1.80 & $\mathrm{P}>0.05$ \\
Ankle Dorsiflexion Muscle Force $(\mathrm{Kg})$ & $11.67 \pm 1.39$ & $13.13 \pm 1.64$ & 1.97 & $\mathrm{P}>0.05$ \\
\hline
\end{tabular}

FRT: Functional Reach Test.

GUG: Timed Get Up Go Test BBS: Berg Balance Scale.

Table 4. Mean values of BBS, FRT, GUG and ankle dorsiflexion muscles strength of group (A) and group (B) at the end of the study.

\begin{tabular}{lllll}
\hline & \multicolumn{2}{c}{ Mean +SD } & T-value & Significance \\
& Group (A) & Group (B) & & \\
\hline BBS & $54.40 \pm 1.68$ & $48.60 \pm 1.72$ & 6.59 & $\mathrm{P}<0.05$ \\
FRT (cm) & $46.53 \pm 2.06$ & $40.00 \pm 3.48$ & 4.59 & $\mathrm{P}<0.05$ \\
GUG (sec) & $9.20 \pm 1.21$ & $12.73 \pm 2.12$ & 4.11 & $\mathrm{P}<0.05$ \\
Ankle Dorsiflexion Muscle Force (Kg) & $18.73 \pm 1.67$ & $13.13 \pm 1.64$ & 6.55 & $\mathrm{P}<0.05$ \\
\hline
\end{tabular}

FRT: Functional Reach Test.

BBS: Berg Balance Scale.

GUG: Timed Get Up Go Test

6.55

$P<0.05$

second. The bursts frequency was reported to be most comfortable by the subject. The current was adjusted to the highest level tolerated by each participant during each session, which lasted for twenty minutes.

Resisted Exercise Training for ankle dorsiflexor muscles: Each patient received an individualized exercise program addressing the specific impairments and functional disabilities identified during the assessment. During exercise training, patients positioned in supine lying position, where resistance was applied to the dorsum of the foot just above the toes to resist dorsiflexion , while stabilization was applied to the lower leg. The amount of resistance increased gradually to be suitable to the participant tolerance. Each subject rested for thirty seconds after each contraction to avoid fatigue.
Duration of exercise training was twenty minutes, three sessions per week for eight weeks.

\section{Statistical analysis}

The mean values of BBS, FRT, GUG and ankle dorsiflexor and plantarflexor muscles strength obtained before and after two months in both groups were compared using paired "t" test. Independent " $t$ " test was used for the comparison between the two groups $(p<0.05)$. Pearson's product moment correlation coefficients $(r)$ were applied to examine the degree of correlation among ankle dorsiflexion muscle force, BBS and TUG.

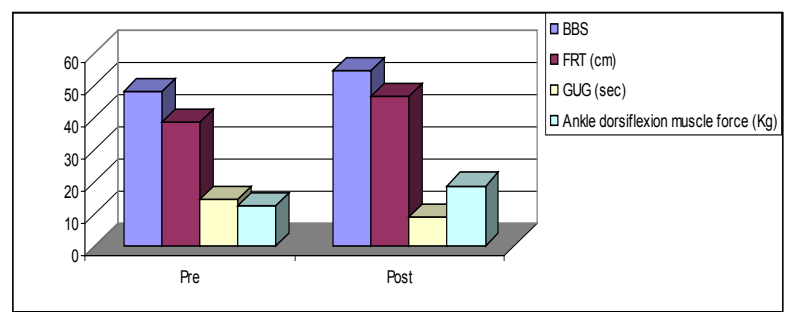

Figure 2. Mean values of BBS, FRT, GUG and ankle dorsiflexion muscles strength of group $(A)$.

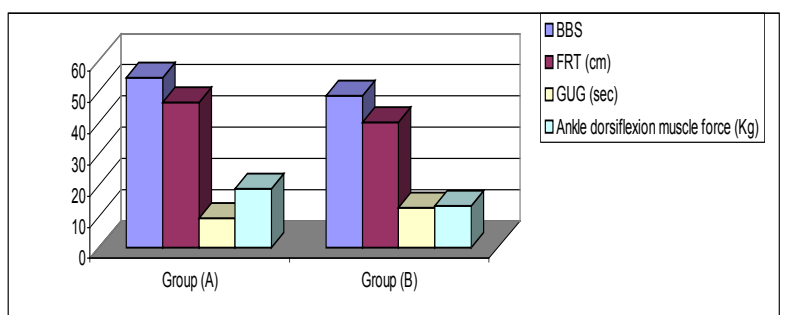

Figure 4. Mean values of BBS, FRT, GUG and ankle dorsiflexion muscles strength of group $(A)$ and group (B) at the end of the study. 
Table 5. Shows the Pearson's correlation coefficients test value and the relationship between the grade of $B B S, F R T, G U G$ and ankle dorsiflexion muscle force in the training group.

\begin{tabular}{lll}
\hline Test & Pearson's value & $\begin{array}{l}\text { Relationship to ankle } \\
\text { dorsiflexion muscle force }\end{array}$ \\
\hline BBS & 0.94 & Strong direct relationship \\
FRT & 0.95 & Strong direct relationship \\
GUG & -0.88 & Strong inverse relationship \\
\hline
\end{tabular}

\section{RESULTS}

There were no statistically significant differences in age, height, weight, or body mass index between subjects in both groups (Table 1). The mean values of BBS , FRT and ankle dorsiflexor strength were significantly increase, where GUG was significantly decreased in group (A) (Table 2, Figure 2), while changes in group (B) were not significant(Table 3, Figure 3) .Also; there were significant differences between both groups at the end of the study (Table 3, Figure 3). The Pearson's correlation coefficients test for the relationship between BBS and ankle dorsiflexor muscles strength in both groups showed a strong direct relationship (Table 4, Figure 4). While, there was an inverse direct relationship GUG and ankle dorsiflexor muscles strength in both groups (Table 5 and Figure 5).

\section{DISCUSSION}

The selection of ankle dorsiflexors in this study depends on the results of the previous studies in this field which indicated that ankle dorsiflexors force was a predictor of balance and fall status. Balance and muscle force deteriorate with aging, it has been suggested that a decrease in the ability to generate force in the lower extremity muscles contributes to balance impairment and falling $(19,20)$.

The results of this study indicated that resisted exercise training and neuromuscular electrical stimulation resulted in improvement of ankle dorsiflexors strength and balance measures among elderly subjects and there was a strong direct correlation between improvement of ankle dorsiflexors muscle strength and balance tests. The improvement of the total scores BBS test after eight weeks of training indicated more control of the body segments, posture and muscles during performing the
Table 6. Shows the Pearson's correlation coefficients test value and the relationship between the grade of $B B S, F R T, G U G$ and ankle dorsiflexion muscle force in the control group.

\begin{tabular}{lll}
\hline Test & Pearson's value & $\begin{array}{l}\text { Relationship to ankle } \\
\text { dorsiflexion muscle force }\end{array}$ \\
\hline BBS & 0.95 & Strong direct relationship \\
FRT & 0.96 & Strong direct relationship \\
GUG & -0.89 & Strong inverse relationship \\
\hline
\end{tabular}

activities of daily living. Increasing the FRT scores and decreasing the time measured in GUG test reflected increase in muscle force, joints flexibility, balance control as well as self confidence and psychological well being.

The results were consistent with the recently published studies which demonstrated that exercise can help to improve balance, reduce falls or fall risk and ability to transfer safely in community- dwelling older adults (2123). It was reported an improvement in balance following high intensity strength training in older adults after a six weeks program of aerobic walking improved balance among older adults, but changes in falls were not reported (24-25). Also, it was reported improvements in static balance in women over the age of sixty years (26), but not in men after three months of strength and flexibility training. Also, exercise training in older adults resulted in decrease in stance postural sway and the exercise group had fewer falls during their experimental tests of balance compared with subjects who did not exercise (27).

The mechanisms for the increased force generating ability following training with electrical stimulation are still unknown. During volitional activation, type I fibers are believed to be recruited first due to small diameter neuron depolarization. Depending on the intensity and duration of the effect and the fatigue level occurring, type II fibers are then recruited according to the size principle. There has been a suggestion that electrical stimulation results in a reversed recruitment order of motor units with earlier and selective activation of type II as decreased force production in elderly is related to decreased muscle mass, decreased muscle fiber number and size (particularly type II fiber atrophy) (28) .

In conclusion, improved strength of dorsiflexors muscles enhanced balance performance in elderly. 


\section{REFERENCES}

1. Tinetti M. Preventing falls in elderly persons. $N$ Engl $J$ Med 2003; 348: 42-9.

2. Royal College of nursing. Clinical practice guideline for the assessment and prevention of falls in older people, Royal College of Nursing, London 2004: 16-28.

3. American Geriatrics Society, British Geriatrics Society, American Academy of Orthopaedic Surgeons. Guidelines for the prevention of falls in older persons. J Am Geriatr Soc 2001; 49: 664-72.

4. Perell K, Nelson A, Goldman R, Luther S, Prieto-Lewis N, Rubenstein L. Fall risk assessment measures: an analytic review. J Gerontol A Biol Sci Med Sci 2001; 56: M761-6.

5. Donald I, Bulpitt C. The prognosis of falls in elderly people living at home. Age Ageing 1999; 28: 121-5.

6. Brown $M$, Sinacore $D$, Host $H$. The relationship of strength to function in the older adult. J Gerontol A Biol Sci Med Sci 1995; 50: 55-9.

7. Horlings C, Van Engelen B, Allum J, Bloem B. A weak balance: the contribution of muscle weakness to postural instability and falls. Nat Clin Prac Neurol 2008; 4: 504-15.

8. Barrett $R$, Hyde S, Scott O, Dubowitz V. Changes in center of gravity in boys with Duchenne muscular dystrophy. Muscle Nerve 1988; 45: 1157-63.

9. Lehmann K, Sunnerhagen K, Willén C. Postural control in persons with late effects of polio. Acta Neurol Scand 2006; 113: 55-61.

10. Lord S, Menz H. Visual contributions to postural stability in older adults. Gerontology 2000; 456: 306-10.

11. Messier S, Royer T, Craven T, O'Toole M, Burns R, Ettinger $W$. Long-term exercise and its effect on balance in older, osteoarthritic adults: results from the Fitness, Arthritis, and Seniors Trial (FAST). J Am Geriatr Soc 2000; 48: 131-8.

12. Buchner D, Cress M, de Lateur B, Esselman P, Margherita $A$, Price $R$. The effect of strength and endurance training on gait, balance, fall risk, and health services use in community-living older adults. J Gerontol A Biol Sci Med Sci 1997; 52: M218-24.

13. Wolf S, Barnhart H, Ellison G, Coogler C. The effect of Tai Chi Quan and computerized balance training on postural stability in older subjects. Atlanta FICSIT Group. Balanceimpaired and injuries: cooperative studies on intervention techniques. Phys Ther 1997; 77: 382-4.

14. Yoon S, Lee J, Kim Y, Kim Y, Cho W, Park C. Change in ankle dorsiflexion range of motion and ultrasonographic images of the tibialis anterior with age. J Physic Ther Sci 2011; 23(5): 813-5.
15. Lord S, Ward J, Williams P, Anstey K. Physiological factors associated with falls in older community-dwelling women. J Am Geriatr Soc 1994; 42: 1110-7.

16. Berg K, Wood-Dauphinee S, Williams J. The balance scale: reliability assessment with elderly residents and patients with an acute stroke. Scand J Rehabil Med 1995; 27: 2736.

17. Mecagni $C$, Smith $P$, Roberts $K$, O'suzllivan S. Balance and ankle range of motion in community- dwelling women aged 64 to 87 years: A co relational study. Phys Ther 2000; 80: 1004-11.

18. Brawn M, Holloszy J. Effects of a low-intensity exercise program on selected physical performance characteristics of 60 to 70 years olds. Aging 1991; 3: 129-39.

19. Daubney M, Culham E. Lower extremity muscle force and balance performance in adults aged 65 years and olderPhys Ther 1999; 79: 1177-85.

20. Tigpen M, Light $K$, Greet $G$. Turning difficulty characteristics of adults aged 65 years or older. Physiotherapy 2000; 80: 1174-1187.

21. Cook S, Gruber W, Baldwin M, Liao S. The effect of multidimensional exercises on balance, Mobility and fall risk in community-dwelling older adults. Phys Ther 1997; 77: 46-57.

22. Province $M$, Hadley $E$, Hornbrook M. The effects of exercise on falls in elderly patients. JAMA 1995; 272: 13411347.

23. Stefen $T$, Haker $T$, Mollinger L. Age and gender-related test performance in community-dwelling elderly people: Six-minute walk test, Berg balance scale, Timed up \& go test and Gait speed. Phys Ther 2002; 82: 128-37.

24. Podsiadlo D, Richardson S. The timed "up and go": a test of basic functional mobility for frail elderly persons. J Am Geriatr Soc 1991; 39: 142-8, 1991.

25. Roberts B. Effects of walking on balance among elders, Nurs Res 1989; 38:180-3.

26. Brawn M, Holloszy J. Effects of a low-intensity exercise program on selected physical performance characteristics of 60 to 70 years olds. Aging 1991; 3: 129-39.

27. Tinetti M, Baker D, Mc-Away G. A multifactorial intervention to reduce the risk of falling among elderly people living in the community N Engl J Med 1994; 331: 821-7.

28. Pfeifer A, Cramfield T, Wagner S, Craik R. Muscle strength: A comparison of electrical stimulation and volitional isometric contractions in adults over 65 years. Physiotherapy Canada 1997; 1: 32-9. 